\title{
INVESTIGATING THE IMPLICATIONS OF ANTI-MICROBIAL AND ANTI-INFLAMMATORY PROPERTIES OF PLUMERIA RUBRA (FRANGIPANI) IN PREVENTING AND TREATING OF DISEASES IN LIVESTOCK FARMS.
}

\author{
Ahaotu, E.O', Nwabueze, E2 , Azubuike, A.P3 and Anyaegbu, F3 \\ IDepartment of Animal Production Technology, Imo State Polytechnic Umuagwo, Nigeria. \\ 2Department of Science Laboratory Technology, Imo State Polytechnic Umuagwo, Nigeria. \\ ${ }^{3}$ Department of Agricultural Technology, Imo State Polytechnic Umuagwo, Nigeria.
}

Email: emmaocy@yahoo.com

\begin{abstract}
Plumeria rubra is small tree commonly known as White Champa Leaf. The leaves and flowers were evaluated for phyto-constituents, used in several traditional medicines to cure various diseases. The plant is mainly grown for its ornamental and fragrant flowers. Leaves arrangement is lanceolate to oblanceolate with flowers, fragrant in corymbose fascicles while the fruit is edible. Their medicinal properties are often due to their latex which is frequently drastic and corrosive. Latex is applied to ulcers, herpes and scabies. Seeds possess hemostatic properties. Plumeria rubra is also used as purgative, cardiotonic, diuretic and hypotensive. The medicinal value of Plumeria rubra is used in the treatment of a large number of human and livestock ailments. The zones of inhibition ranges from 10-28 $\mathrm{mm}$ and the plant extracts showed a broad spectrum of antimicrobial activity against gram positive and gram-negative bacteria. It was more pronounced on gram negative bacteria especially Proteus mirabilis. Also, the ethyl acetate crude extract was effective against Pseudomonas aeruginosa which is resistant to most antimicrobial agents. The extracts were also effective against the fungi Candida albicans. The results of the study can provide suitable standards for the prevention and treatment of diseases in livestock farms.
\end{abstract}

KEYWORDS: Plumeria rubra, Antimicrobial, Anti-inflammatory, Leaves, Flowers, Inhibitory concentration; Bactericidal concentration; Lethal concentration 


\section{INTRODUCTION}

Plumeria rubra (Apocynaceae) is a small laticiferous tree, native to tropical America (Dubey et al., 2014 and Radha, 2008). It is $4.5 \mathrm{~m}$ high, occasionally grown for its ornamental and fragrant flowers. Leaves are lanceolate to oblanceolate while flowers have white fragrant which are in corymbose fascicles (Kumar et al., 2012). The fruit is edible, latex is applied to ulcers, herpes and scabies while seeds possess haemostatic properties (Bawa et al., 2019). Moreover its bark is bruised and applied as plaster over hard tumours (Kumar et al., 2009). Uduji et al., (2020) reported that the plant contains amyrinacetate mixtures of amyrin, B- sitosterol, scopotetin, the iriddoids isoplumericin, plumieride, plumieride coumerate and plumieride coumerate glucoside.

The plant material is widely used as a purgative, febrifuge and remedy for diarrhoea and cure for itch. The leaves were reported to have analgesicantipyretic, anti-inflammatory, and antioxidant properties. Odoemelam et al., (2020) indicated that $10 \mathrm{~kg}$ of Plumeria rubra leaf meal added to the diet of Hyline brown birds favours hen day production, egg weight, shell weight and feed efficiency of the tested animals. Uduji et al., (2020) further reported that the appreciable level of fat in the Plumeria rubra flower meal based diets as additives might have accounted for the egg weight of birds fed these diets. The flowers were also reported to be useful as antioxidant and hypolipidemic (Sura et al., 2018).
Leaves are simple, arranged in a whorl, with prominent veins, crowded at the end of branches. In traditional medicinal system different parts of the plant have been mentioned to be useful in a variety of diseases (Dubey et al., 2014 and Dhanapal et al., 2018).

Flowers are of different kinds like white, reddish pink and bluish with fragrance (Rupali and Alka, 2014). The Pink flowers of Plumeria is due to phenolic compound and is found to be a good source of natural dye for cloth (Kalam et al., 2014 and Reddy et al., 1999). Root is bitter, carminative, and thermogenic (llyas et al., 2016 and Sura et al., 2018). Leaves are useful in inflammation, rheumatism, antibacterial, antifungal, bronchitis and antipyretic (Gunja et al., 2017). Extract of leaves of Plumeria rubra (L.) showed significant antibacterial activity against Streptoccocus. Epidermidis and Escherischia strains (Singh, 2010). Methanolic extract showed antimicrobial activity against Bacillus anthracis, Pseudomonas aeruginosa. The plant is reported to contain amyrinacetate, mixture of amyrins, B-sitosterol, scopotetin, the iriddoids isoplumericin, plumieride, plumieride coumerate and plumieride coumerate glucoside (Egwaikhide et al., 2009 and Kumar et al., 2011). Pod has abortifacient and hepatoprotective effects (Dawada, 2015 and Santhi, 2010). Bark is antinociceptive and antiinflammatory. Leaves are found to have antiulcer activity, whereas flowers have 
profound antioxidant effects (Ogunwande et al., 2015). Flower of Plumeria was found to be a good source of natural dye for producing various green, ivory and brown shades on silk cloth.

The emergence of antimicrobial resistant bacteria pathogens has become a major public health concern. The use of antimicrobials in any area including disease treatment can potentially lead to widespread dissemination of antimicrobial resistant bacteria. The increasing prevalence of antimicrobial drug-resistant bacteria is a major concern to human and veterinary medicine. Resistant bacteria include both pathogens and commensal organism, with the later serving as a potential reservoir for mobile resistant elements. Since the plant kingdom still holds many species of plants containing substances of medicinal values, which are yet to be discovered. Plumeria rubra is one of the plants which have been used in traditional medicine for many years (Oladipupo et al., 2015).

This study is therefore designed to investigate the implications of the antimicrobial and anti-inflammatory properties of true frangipani (Plumeria rubra) for the prevention and treatment of diseases in livestock farms, test for the activities of the hexane, ethyl acetate and methanol leaf and flower extracts of Plumeria rubra against four species of Gram negative and ten species of Gram positive bacteria strains. The results of the preliminary phytochemical analysis will provide suggestions as to the secondary metabolites responsible for the activities of the extracts.

\section{MATERIALS AND METHODS Collection and Authentication}

Plumeria rubra leaves were collected, from in and around the botany garden of the Forestry Department, Imo State Polytechnic Umuagwo, Nigeria and authenticated by taxonomist and the plant authenticated specimen is deposited in the Department of Science Laboratory Technology of the institution. Authentication specimens of the fresh leaves were kept for shade drying. Dried specimen was powdered using mechanical grinder and passed through 60 mesh sieve to get the powder of desired coarseness. Powdered material was preserved in an air tight container.

\section{Extraction of Plant material}

For preliminary phytochemical analysis, extract was prepared by weighing $1 \mathrm{~kg}$ of the dried powdered leaf was subjected to hot successive continuous extraction with different solvents as per the polarity, petroleum ether, benzene, chloroform, ethanol and aqueous. The extracts were filtered in each step using Whatman filters paper (Aggarwal and Paridhavi, 2007). The filtrate was concentrated using a rotary evaporator at low temperature (40$45^{\circ} \mathrm{C}$ ) and pressure. The presence or absence of the primary and secondary Phyto-constituents was detected by usual prescribed methods (Dhanapal et al., 2018).

\section{Preparation of Crude Extract}


The flowers collected was dried under shade and then powdered with a mechanical grinder and stored in airtight container. The dried powder material of the flowers was defatted with n-hexane and allowed to dry. The product thus obtained was then extracted with methanol in a Soxhlet apparatus. The solvent was completely removed under reduced pressure and a semisolid mass was obtained.

\section{Microorganisms}

The two positive bacterial strains Bacillus subtilis, Staphylococcus aureus and two negative bacterial strains Pseudomonas aeruginosa, Escherichia coli including one fungal strain Candida albicans are collected for their antimicrobial testing from Department of Science Laboratory Technology, Imo State Polytechnic Umuagwo, Nigeria.

\section{Antimicrobial assay}

Disc diffusion method (Garba and Okeniyi, 2010) was used to test the antimicrobial activity of the extracts against four bacterial strains and one fungal strain (Table-5). Dried and sterilized filter paper discs (6 $\mathrm{mm}$ diameter) were then impregnated with known amount of the test substances dissolved in methanol (30 $\mu \mathrm{g} / \mathrm{ml}$ ) and water separately using micropipette and the residual solvents were completely evaporated (Doughari, 2006). Discs containing the test material with different concentrations each were placed on nutrient agar medium for bacterial strains and Sabouraud Dextrose Agar (SDA) for fungal strain uniformly seeded with the test microorganisms.

Negative controls were prepared using the same solvents as employed to obtain the extracts. As positive controls, Ciprofloxacin (10 $\mathrm{\mu g} / \mathrm{ml})$ was used for Gram-positive and Gram-negative bacteria and Fluconazole $(10 \mu \mathrm{g} / \mathrm{ml})$ for Candida spp. The inoculated plates were incubated at $37^{\circ} \mathrm{C}$ for $24 \mathrm{~h}$ for clinical bacterial strains and at $35^{\circ} \mathrm{C}$ for 48 $\mathrm{h}$ for fungal strain (yeast). The test materials having antimicrobial activity inhibited the growth of the microorganisms and a clear, distinct zone of inhibition was visualized surrounding the disc. The antimicrobial activity of the test agents was determined by measuring the diameter of zone of inhibition in millimeter.

\section{Physico chemical features}

The powdered drug was evaluated for its physico-chemical parameters like total ash values, acid insoluble ash, water soluble ash and loss on drying, and the results were tabulated (Table 1). 
Table 1. Physico - Chemical Evaluation of the Crude Drug of Leaf of Plumeria rubra.

S/No Physical Evaluation

$\% \mathrm{w} / \mathrm{w}$

\begin{tabular}{lll} 
1. & Total Ash & 6.03 \\
2. & Acid Insoluble Ash & 3.94 \\
3. & Water Soluble Ash & 2.42 \\
4. & Loss on Drying & 0.5 \\
\hline
\end{tabular}

Table 2. Preliminary Phytochemical Tests for Drug Powder and Various Extracts of Leaf of Plumeria rubra.

\begin{tabular}{|l|l|l|l|l|l|l|l|}
\hline $\begin{array}{l}\text { S. } \\
\text { No }\end{array}$ & Test & $\begin{array}{l}\text { Drug } \\
\text { Powder }\end{array}$ & $\begin{array}{l}\text { Petroleum } \\
\text { Ether } \\
\text { Extract }\end{array}$ & Benzene Extract & $\begin{array}{l}\text { Chloroform } \\
\text { Extract }\end{array}$ & $\begin{array}{l}\text { Ethanol } \\
\text { Extract }\end{array}$ & $\begin{array}{l}\text { Aqueous } \\
\text { Extract }\end{array}$ \\
\hline 1. & Sterols & + & + & + & + & + & - \\
\hline 2. & Terpenoids & - & - & - & - & + & + \\
\hline 3. & Carbohydrates & + & - & - & - & - \\
\hline 4. & Flavonoids & + & - & - & - & + & + \\
\hline 5. & Proteins & + & - & - & - & + & + \\
\hline 6. & Alkaloids & + & - & - & - & + & + \\
\hline 7. & Glycosides & - & - & - & - & + & + \\
\hline 8. & Saponins & + & - & - & - & - & - \\
\hline 9. & Tannins & + & - & - & - & + & + \\
\hline 10. & Mucilages & + & - & - & - & + & + \\
\hline 11. & Volatile Oil & + & - & - & - & + & + \\
\hline
\end{tabular}

+ indicates positive reaction, -indicates negative reaction.

+ indicates positive reaction, -indicates negative reaction.

Table 3: Fluorescence analysis of leaf of plumeria rubra.

\begin{tabular}{llll}
\hline S. No & Sample & Colour in Day Light & Colour in UV Light \\
\hline 1. & Petroleum ether extracts & Pale green & Dark green \\
2. & Benzene Extract & Green & Light green \\
3. & Chloroform Extract & Brownish green & Green \\
4. & Ethanol Extract & Green & Dark Green \\
5. & Aqueous Extract & Brownish green & Yellowish green \\
\hline
\end{tabular}

\section{Fluorescence analysis of the extracts}

The extracts were prepared as per their polarity in hot successive extraction technique and they were treated with reagents and the colour changes were observed under Ultra Violet light and the results were tabulated (Table 3). 
Table 4: Extractive values of leaf of plumeria rubra with different solvents.

\begin{tabular}{llc}
\hline S. No & Sample & Extractability (\%) \\
\hline 1. & Petroleum ether extracts & 9.5 \\
2. & Benzene Extract & 7.2 \\
3. & Chloroform Extract & 5.8 \\
4. & Ethanol Extract & 6.7 \\
5. & Aqueous Extract & 9.2 \\
\hline
\end{tabular}

\section{Extractive values}

The extracts were prepared according to the polarity and they were concentrated and their values were calculated with reference to air dried drug and the results were tabulated (Table 4).

All the extracts of the drug was subjected to different tests for detecting the presence of various phyto-constituents present in the drug, which revealed the presence of sterols, flavonoids, alkaloids, saponins, proteins, carbohydrate, volatile oil and tannins. Preliminary phytochemical analysis indicated a high percentage of quercetin and flavonoids and this may be one of the reasons behind the sedative activity of the plant. These parameters, which are being reported for the first time in this plant, are significant towards establishing the Pharmacognostic standards for future identification and authentication of genuine plant material.

Table 5. Antimicrobial activity of Plumeria rubra bark Linn.

\begin{tabular}{|c|c|c|c|c|c|}
\hline S.No & $\begin{array}{l}\text { Sample } \\
\text { Name }\end{array}$ & Organism & Concentration of Sample & Zone Diameter & Bore Size \\
\hline \multirow[t]{3}{*}{1.} & \multirow[t]{3}{*}{ Methanol Extract } & $\begin{array}{l}\text { Bacillus } \\
\text { Subtilis }\end{array}$ & $\begin{array}{l}10 \mathrm{mcg} \backslash \mathrm{ml} \text { (Ciprofloxacin) } \\
8000 \mathrm{mcg} \backslash \mathrm{ml} \\
4000 \mathrm{mcg} \backslash \mathrm{ml} \\
2000 \mathrm{mcg} \backslash \mathrm{ml} \\
1000 \mathrm{mcg} \backslash \mathrm{ml}\end{array}$ & $\begin{array}{l}25.87 \mathrm{~mm} \\
19.91 \mathrm{~mm} \\
18.64 \mathrm{~mm} \\
17.24 \mathrm{~mm} \\
14.12 \mathrm{~mm}\end{array}$ & $\begin{array}{l}6 \mathrm{~mm} \\
6 \mathrm{~mm} \\
6 \mathrm{~mm} \\
6 \mathrm{~mm} \\
6 \mathrm{~mm}\end{array}$ \\
\hline & & $\begin{array}{l}\text { Staphylococcus } \\
\text { aureus }\end{array}$ & $\begin{array}{l}10 \mathrm{mcg} \backslash \mathrm{ml} \text { (Ciprofloxacin) } \\
8000 \mathrm{mcg} \backslash \mathrm{ml} \\
4000 \mathrm{mcg} \backslash \mathrm{ml} \\
2000 \mathrm{mcg} \backslash \mathrm{ml} \\
1000 \mathrm{mcg} \backslash \mathrm{ml}\end{array}$ & $\begin{array}{l}28.33 \mathrm{~mm} \\
23.11 \mathrm{~mm} \\
19.58 \mathrm{~mm} \\
16.56 \mathrm{~mm} \\
12.71 \mathrm{~mm}\end{array}$ & $\begin{array}{l}6 \mathrm{~mm} \\
6 \mathrm{~mm} \\
6 \mathrm{~mm} \\
6 \mathrm{~mm} \\
6 \mathrm{~mm}\end{array}$ \\
\hline & & $\begin{array}{l}\text { Pseudomonas } \\
\text { aeruginosa }\end{array}$ & $\begin{array}{l}10 \mathrm{mcg} \backslash \mathrm{ml} \text { (Ciprofloxacin) } \\
8000 \mathrm{mcg} \backslash \mathrm{ml} \\
4000 \mathrm{mcg} \backslash \mathrm{ml} \\
2000 \mathrm{mcg} \backslash \mathrm{ml} \\
1000 \mathrm{mcg} \backslash \mathrm{ml}\end{array}$ & $\begin{array}{l}28.75 \mathrm{~mm} \\
24.14 \mathrm{~mm} \\
22.08 \mathrm{~mm} \\
18.36 \mathrm{~mm} \\
15.47 \mathrm{~mm}\end{array}$ & $\begin{array}{l}6 \mathrm{~mm} \\
6 \mathrm{~mm} \\
6 \mathrm{~mm} \\
6 \mathrm{~mm} \\
6 \mathrm{~mm}\end{array}$ \\
\hline
\end{tabular}




\begin{tabular}{|c|c|c|c|c|c|}
\hline & & $\begin{array}{l}\text { Escherichia } \\
\text { Coli }\end{array}$ & $\begin{array}{l}10 \mathrm{mcg} \backslash \mathrm{ml} \text { (Ciprofloxacin) } \\
8000 \mathrm{mcg} \backslash \mathrm{ml} \\
4000 \mathrm{mcg} \backslash \mathrm{ml} \\
2000 \mathrm{mcg} \backslash \mathrm{ml} \\
1000 \mathrm{mcg} \backslash \mathrm{ml}\end{array}$ & $\begin{array}{l}30.00 \mathrm{~mm} \\
26.35 \mathrm{~mm} \\
23.17 \mathrm{~mm} \\
16.68 \mathrm{~mm} \\
11.88 \mathrm{~mm}\end{array}$ & $\begin{array}{l}6 \mathrm{~mm} \\
6 \mathrm{~mm} \\
6 \mathrm{~mm} \\
6 \mathrm{~mm} \\
6 \mathrm{~mm}\end{array}$ \\
\hline & & $\begin{array}{l}\text { Candida } \\
\text { albicans }\end{array}$ & $\begin{array}{l}10 \mathrm{mcg} \backslash \mathrm{ml} \text { (Ciprofloxacin) } \\
8000 \mathrm{mcg} \backslash \mathrm{ml} \\
4000 \mathrm{mcg} \backslash \mathrm{ml} \\
2000 \mathrm{mcg} \backslash \mathrm{ml} \\
1000 \mathrm{mcg} \backslash \mathrm{ml}\end{array}$ & $\begin{array}{l}17.36 \mathrm{~mm} \\
11.23 \mathrm{~mm} \\
10.41 \mathrm{~mm} \\
9.15 \mathrm{~mm} \\
8.58 \mathrm{~mm}\end{array}$ & $\begin{array}{l}6 \mathrm{~mm} \\
6 \mathrm{~mm} \\
6 \mathrm{~mm} \\
6 \mathrm{~mm} \\
6 \mathrm{~mm}\end{array}$ \\
\hline \multirow[t]{5}{*}{2.} & \multirow[t]{5}{*}{ Water Extract } & $\begin{array}{l}\text { Bacillus } \\
\text { Subtilis }\end{array}$ & $\begin{array}{l}10 \mathrm{mcg} \backslash \mathrm{ml} \text { (Ciprofloxacin) } \\
8000 \mathrm{mcg} \backslash \mathrm{ml} \\
4000 \mathrm{mcg} \backslash \mathrm{ml} \\
2000 \mathrm{mcg} \backslash \mathrm{ml} \\
1000 \mathrm{mcg} \backslash \mathrm{ml}\end{array}$ & $\begin{array}{l}23.19 \mathrm{~mm} \\
13.38 \mathrm{~mm} \\
9.21 \mathrm{~mm} \\
\text { Nil } \\
\text { Nil }\end{array}$ & $\begin{array}{l}6 \mathrm{~mm} \\
6 \mathrm{~mm} \\
6 \mathrm{~mm} \\
6 \mathrm{~mm} \\
6 \mathrm{~mm}\end{array}$ \\
\hline & & $\begin{array}{l}\text { Staphylococcus } \\
\text { aureus }\end{array}$ & $\begin{array}{l}10 \mathrm{mcg} \backslash \mathrm{ml} \text { (Ciprofloxacin) } \\
8000 \mathrm{mcg} \backslash \mathrm{ml} \\
4000 \mathrm{mcg} \backslash \mathrm{ml} \\
2000 \mathrm{mcg} \backslash \mathrm{ml} \\
1000 \mathrm{mcg} \backslash \mathrm{ml}\end{array}$ & $\begin{array}{l}25.91 \mathrm{~mm} \\
9.22 \mathrm{~mm} \\
8.61 \mathrm{~mm} \\
8.01 \mathrm{~mm} \\
7.38 \mathrm{~mm} \\
\end{array}$ & $\begin{array}{l}6 \mathrm{~mm} \\
6 \mathrm{~mm} \\
6 \mathrm{~mm} \\
6 \mathrm{~mm} \\
6 \mathrm{~mm} \\
\end{array}$ \\
\hline & & $\begin{array}{l}\text { Pseudomonas } \\
\text { aeruginosa }\end{array}$ & $\begin{array}{l}10 \mathrm{mcg} \backslash \mathrm{ml} \text { (Ciprofloxacin) } \\
8000 \mathrm{mcg} \backslash \mathrm{ml} \\
4000 \mathrm{mcg} \backslash \mathrm{ml} \\
2000 \mathrm{mcg} \backslash \mathrm{ml} \\
1000 \mathrm{mcg} \backslash \mathrm{ml}\end{array}$ & $\begin{array}{l}24.5 \mathrm{~mm} \\
7.88 \mathrm{~mm} \\
7.01 \mathrm{~mm} \\
\text { Nil } \\
\text { Nil }\end{array}$ & $\begin{array}{l}6 \mathrm{~mm} \\
6 \mathrm{~mm} \\
6 \mathrm{~mm} \\
6 \mathrm{~mm} \\
6 \mathrm{~mm} \\
\end{array}$ \\
\hline & & $\begin{array}{l}\text { Escherichia } \\
\text { Coli }\end{array}$ & $\begin{array}{l}10 \mathrm{mcg} \backslash \mathrm{ml} \text { (Ciprofloxacin) } \\
8000 \mathrm{mcg} \backslash \mathrm{ml} \\
4000 \mathrm{mcg} \backslash \mathrm{ml} \\
2000 \mathrm{mcg} \backslash \mathrm{ml} \\
1000 \mathrm{mcg} \backslash \mathrm{ml}\end{array}$ & $\begin{array}{l}31.75 \mathrm{~mm} \\
8.58 \mathrm{~mm} \\
7.51 \mathrm{~mm} \\
7.04 \mathrm{~mm} \\
\text { Nil }\end{array}$ & $\begin{array}{l}6 \mathrm{~mm} \\
6 \mathrm{~mm} \\
6 \mathrm{~mm} \\
6 \mathrm{~mm} \\
6 \mathrm{~mm}\end{array}$ \\
\hline & & $\begin{array}{l}\text { Candida } \\
\text { albicans }\end{array}$ & $\begin{array}{l}10 \mathrm{mcg} \backslash \mathrm{ml} \text { (Ciprofloxacin) } \\
8000 \mathrm{mcg} \backslash \mathrm{ml} \\
4000 \mathrm{mcg} \backslash \mathrm{ml} \\
2000 \mathrm{mcg} \backslash \mathrm{ml} \\
1000 \mathrm{mcg} \backslash \mathrm{ml}\end{array}$ & $\begin{array}{l}15.36 \mathrm{~mm} \\
8.22 \mathrm{~mm} \\
8.07 \mathrm{~mm} \\
7.62 \mathrm{~mm} \\
7.11 \mathrm{~mm}\end{array}$ & $\begin{array}{l}6 \mathrm{~mm} \\
6 \mathrm{~mm} \\
6 \mathrm{~mm} \\
6 \mathrm{~mm} \\
6 \mathrm{~mm}\end{array}$ \\
\hline
\end{tabular}

Kumar et al., (2012).

\section{Antimicrobial activities}

These were done according to the disc diffusion method (Bawa et al., 2019). For the test, $100 \mathrm{mg}$ of the crude extract of Plumeria rubra was accurately measured by the electronic balance and taken into vial. Then one $\mathrm{ml}$ of ethanol was added and triturated in uni-directional manner. Both gram positive and gram negative bacteria were used. The bacteria used for the anti-microbial activity of Ethanolic crude extract of the Plumeria rubra were Escherichia coli, Salmonella typhi, Salmonella paratyphi, Shigella dysenteriae, 
Staphylococcus aureus, Streptococcus pyogenes. In this method, measured amount of the test samples were dissolved in definite volumes of solvent to give solutions of known concentration $(\mu \mathrm{g} / \mathrm{ml})$. Then sterile Matricel (BBL, Cookeville, USA) filter paper discs are impregnated with known amount of test substances using micropipette and dried. Standard antibiotic discs and discs on which the solvent used to dissolve the samples is adsorbed and dried were used as positive and negative controls respectively. These discs are then placed in petri-dishes 1120 $\mathrm{mm}$ in diameter) containing a suitable agar medium seeded with the test organisms using sterile transfer loop for antimicrobial evaluation. The plates are then kept at $40^{\circ} \mathrm{C}$ for facilitating maximum diffusion. The test material diffuses from the discs to the surrounding medium. The plates are then kept in an incubator for 1824 hours to allow the growth of the microorganisms. The antibacterial activity of the test agent is determined by measuring the diameter of the zone of inhibition in term of millimeter. It is concluded that the plant possesses potent antimicrobial activity (Gupta et al., 2008).

\section{Anti-inflammatory and anthelmintic activities}

The methanolic extract of Plumeria rubra exhibited significant anti-inflammatory activity on the tested experimental animal models. The extract $(500 \mathrm{mg})$ exhibited maximum anti-inflammatory effect. Carrageenan-induced oedema has been commonly used as an experimental animal model for acute inflammation and is believed to be biphasic. The cotton pellet method is widely used to evaluate the proliferative components of the chronic inflammation. The results obtained in this study indicated that the methanol extract of $P$. rubra possess potent antiinflammatory activity in both acute and chronic models (Gupta et al., 2006).

The saponins extract was used for testing anti-inflammatory and anthelmintic activity of $P$. rubra leaves. The anti-inflammatory activity was evaluated by determining the reduction in carrageenan induced hind paw edema in albino mice. The result of the maximum dose of $200 \mathrm{mg} / \mathrm{kg}$ P. rubra extract exhibited a significant reduction in the volume of inflammation. The anthelmintic effect of $P$. rubra extract of $25 \mathrm{mg} / \mathrm{ml}$ concentration is comparable with that of the effect produced by reference standards piperazine citrate on Indian adult earthworms (Pheretima posthuma) (Kumar et al., 2012). The chloroform and ethanolic extract of $P$ rubra leaves shows antiulcer activity in albino rats.

The results of the antimicrobial screening have been represented in Table 5 . The zone of inhibition of methanol extract ranged from $11.88 \mathrm{~mm}$ to $26.35 \mathrm{~mm}$. The highest inhibition zone $26.35 \mathrm{~mm}$ was formed by the methanol extract of Plumeria rubra against Escherichia coli at the highest concentration followed by Pseudomonas aeruginosa, Staphylococcus aureus and Bacillus subtilis. The zone of inhibition of water extract of Plumeria rubra Linn. was less than that of the methanol 
extract and ranged from $7.01 \mathrm{~mm}$ to 13.38 $\mathrm{mm}$. The highest inhibition zone $13.38 \mathrm{~mm}$ was formed by water extract of Plumeria rubra against Bacillus subtilis. The methanol extract that showed antibacterial activity against the pathogens was active in all the given concentration i.e. 8000, 4000, 2000 and $1000 \mu \mathrm{g} / \mathrm{ml}$, whereas water extract showed activity at the concentration of 8000 and $4000 \mathrm{mcg} / \mathrm{ml}$ but the lower concentrations 2000 and $1000 \mathrm{\mu g} / \mathrm{ml}$ showed no activity against Bacillus subtilis and Pseudomonas aeruginosa.

Methanol extract as well as water extract of Plumeria rubra also showed a significant zone of inhibition against a fungal species, Candida albicans at all the given concentrations (Table 5). In vitro antibacterial activity of Plumeria rubra bark against Gram positive Staphylococcus aureus, Bacillus subtilis, Gram negative Pseudomonas aeruginosa, Escherichia coli, and fungal species Candida albicans was carried out and methanol extract showed significant results against pathogens than that of water extract of Plumeria rubra Linn.

The results of this investigation should be helpful in the further experiments on antimicrobial activity of Plumeria rubra bark. These studies confirms the potential of this plant but further more mechanistic work is essential to prove it as one of the specific antimicrobial plant.

\section{DISCUSSION}

All the extracts of the drug was subjected to different tests for detecting the presence of various phyto-constituents present in the drug, which revealed the presence of sterols, flavonoids, alkaloids, saponins, proteins, carbohydrate, volatile oil and tannins (Tables 2, 3 and 4). Preliminary phyto-chemical analysis indicated a high percentage of quercetin and flavonoids and this may be one of the reasons behind the sedative activity of the plant. These parameters, which are being reported for the first time in this plant, are significant towards establishing the Pharmacognostic standards for future identification and authentication of genuine plant material. Though Plumeria rubra is a temple tree, it is a highly reputed drug used for the prevention and treatment of diseases in animal agriculture.

The literature survey revealed that the various species of Plumeria is an important source of many pharmacologically and medicinally important chemicals such as plumieride, isoplumeride, fluvoplumericin, irriod glycoside and other various minor secondary metabolites. Study of pharmacological activities with different extracts obtained from different parts of the plant (Fig: 1, 2 and 3) with difference in vitro and in vivo model, which show that the compounds have beneficial effects against a number of diseases. The plant has been widely studied for its pharmacological activities and regarded as universal panacea in ethno - veterinary medicines and find its position as a versatile plant having a wide spectrum of medicinal activities. Plumeria rubra appears to have significant antimicrobial capacity resembling a broad spectrum 2020 September Edition | www.jbino.com | Innovative Association 
antibiotic against the common uro-gastro pathogenic Escherichia coli, one of the common bacteria with pathogenic strains and are relatively resistant towards synthetic drugs (Syakira and Brenda, 2010). As the global scenario is now changing towards the use of non-toxic plant products, development of modern drugs from Plumeria species should be emphasized.

Ursolic acid from the leaves, plumeric acid from the latex, leaves and fulvoplumerin from the bark of $P$. rubra possess local anesthetic, cardiotonic and bacteriostatic activities respectively. P.rubra containing fulvoplumerin acts as inhibitors of human immunodeficiency virus type 1 (HIV) revereasetrancriptase. Methanolic extract of P.rubra showed hepatoprotective action against paracetamol induced hepatic damage. Ethanolic extract of Plumeria rubra. (Apocynaceae) leaves and flowers were tested for antimicrobial activity against Gram-positive bacteria (Bacillus subtilis, Enterococcus faecalis and Staphylococcus aureus), Gram-negative bacteria (Escherichia coli, Klebsiella Pneumonias, Pseudomonas aeruginosa, Salmonella typhimurium) and fungi
(Aspergillus niger and candida albicans) by disc diffusion method. The ethanol extract showed strong in vitro antimicrobial activity against E. faecalis, B. subtilis, $S$. aureus, $P$. aeruginosa, S. typhimurium, A. niger and C. albicans respectively (Rasool et al., 2008).

Plumeria rubra extracts were evaluated for antimicrobial activity using cup plate method and minimum inhibitory concentration against Escheria Coli, Bacillus subtilis, Staphylococcus aureus and Aspergillus niger. It was observed that a methanol extract exhibited significant activity against bacterial strains. When compared with Ciprofloxacin as a standard, aqueous extract was active against fungal strains as compared with standard Fluconazole (Surendra et al., 2012).

Methanolic extract of $P$. rubra leaves possesses significant antitumor activity against Dalton lymphoma ascites in mice result shows that methanolic extract of $P$. alba can significantly prolong the life span, reduce tumour volume and improve the hematological parameters of the host (mice) (Radha et al., 2008). 


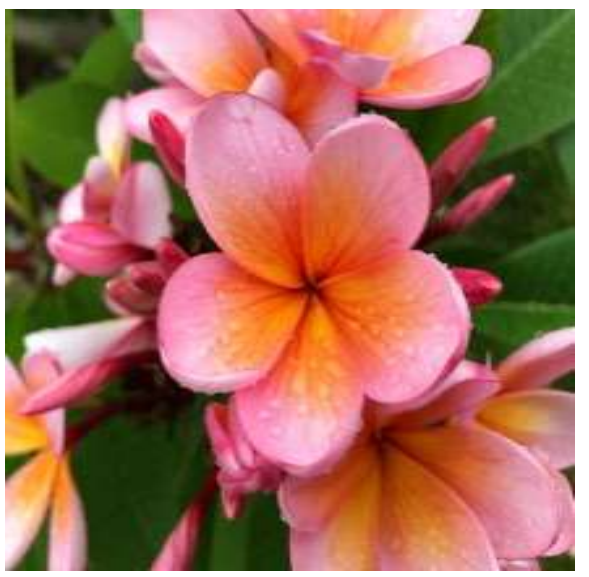

Fig 1 a: Plumeria rubra

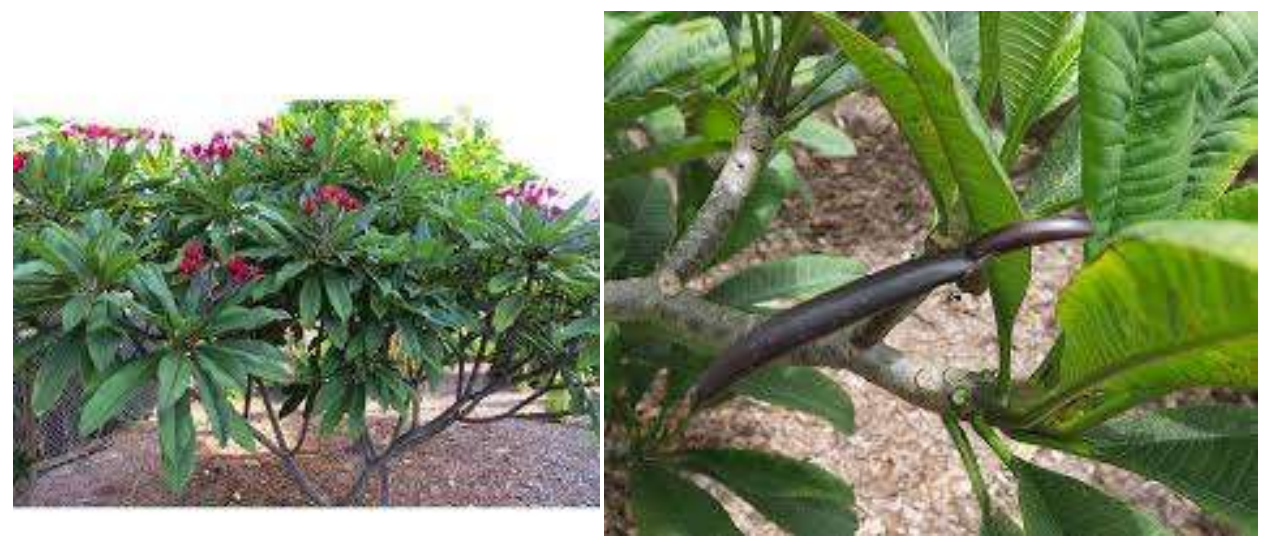

Flowers

Fig 1b: Plumeria rubra Plant Fig 1c: Plant displaying the Pods
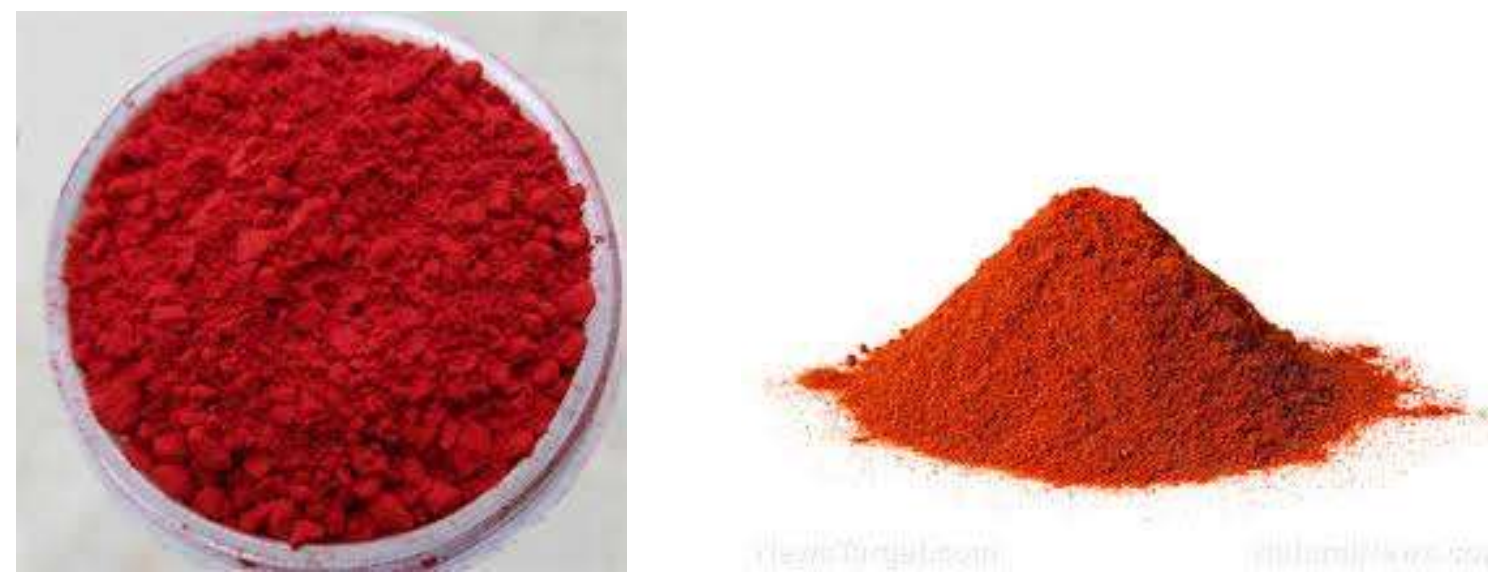

Fig 2: Plumeria rubra flower meal.
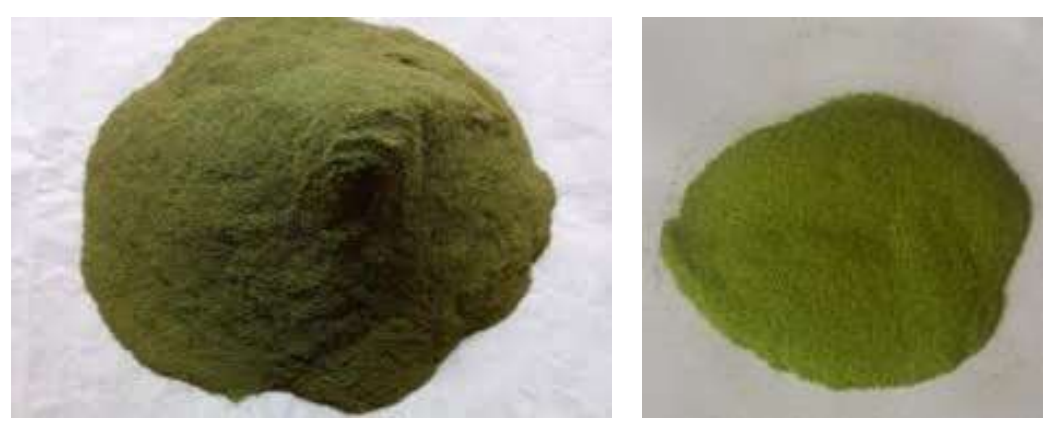

Fig 3: Plumeria rubra leaf meal.

\section{CONCLUSION}

It is reasonable from the result obtained to suggest that the plant extracts possess broad spectrum antimicrobial activity. The antimicrobial activity was more pronounced in the gram-negative 2020 September Edition | www.jbino.com | Innovative Association 
Staphylococcus aureus, a gram-negative bacterium. The plant extract was also effective against the fungi Candida albicans.

In the present study various standardization parameters such as macroscopy, microscopy (histochemical and powder), physicochemical standards, preliminary phytochemical investigation, which are being reported for the first time in this plant could be helpful in authentication and preparation of a suitable monograph for the proper identification of Plumeria rubra for the future.

The prevention of oxidative damage to tissue could therefore be one of the mechanisms responsible for the antiinflammatory effect shown by this plant. Confirmation of the anti-inflammatory activity in animal model further justifies the traditional use of this plant for inflammatory disorders. The ethno medical use of P.rubra as a useful remedy in inflammatory and arthritic disorders could possibly be because of its excellent anti-inflammatory and antioxidant potential.

\section{ACKNOWLEDGEMENT}

The authors are thankful to the Director of Tetfund Institution - Based Intervention for providing funds and facilities to carry out the present research.

\section{REFERENCES}

Aggarwal S.S and Paridhavi M (2007). Extraction, isolation and analysis of phyto- pharmaceuticals, Herbal Drug Technology. pp. 325- 326.

Bawa, E, Kagoro, M. L and Wapwera, J (2019). A Study on the Phytochemical and Antimicrobial Screening of Ethyl acetate Extract of Plumeria rubra Leaves and Stems Bark. Agri Res \& Tech: Open Access J. 2019; $21(4)$ : 556170.

10.19080/ARTOAJ.2019.21.556170

Dawada S.D (2015). Hepatoprotective activity of pod extract of Plumeria rubra against carbon tetra chloride induced hepatic injury in rats (Wistar). Int J Pharm Sci. 3 (3) :218-227.

Dhanapal, V, Samuel, T. B and Muddukrishniah," S (2018). Pharmocognostical and phytochemical evaluation of leaf of Plumeria rubra. World Journal of Pharmaceutical Research. 7 (4). $605-616$.

Doughari J.H (2006). Antimicrobial Activity of Tamarindus indica Linn. Tropical Journal of Pharmaceutical Research, December 5 (2): 597-603.

Dubey NK, Kumar R and Tripathi P (2014). Global promotion of herbal medicines. India's opportunity. Current Science. 86:37- 41.

Egwaikhide $P$, Okeniyi $S$ and Gimba $C$ (2009). Screening for antimicrobial activity and phytochemical constituents of some Nigerian medicinal plants Journal of Medicinal Plants Research. 3:1088-1091. 
Garba. S and Okeniyi so (2012). Antimicrobial activities of total alkaloids extracted from some Nigerian medicinal plants, Journal of Microbiology and Antimicrobials. Vol. 4(3): 60-63.

Gunja S, Abhishek G, Manjul P. S and Anurag M (2017). Pharmacognostic Standardization and Chromatographic Fingerprint Analysis on Triterpenoids Constituents of the Medicinally Important Plant Plumeria rubra f. rubra by HPTLC technique. Pharmacogn J. 9 (2): 135-141

Gupta M, Mazumder UK, Gomathi P and Thamil SV (2006). Anti-inflammatory evaluation of leaves of Plumeria acuminata. BMC Complementary and alternative medicine. 6 (36):1472-6882.

Gupta M, Mazumder UK, Gomathi P and Thamil V (2008). Antimicrobial activity of methanol extracts of Plumeria acuminata Ait. leaves and Tephrosia purpurea (Linn.) Roots. Persian Journal of Natural Product Radiance. 7(2):102-105.

Kalam S, Yegnambhatla R, Periyasamy G, Meesa $M$, Guggulothu $H$ and Yegnambhatla A (2014). Comparative Phytochemical and Pharmacological Evaluation of flowers of Plumeria rubra L. $\mathrm{f}$. rubra and Plumeria rubra f. lutea. British Biomedical Bulletin 2 (1): 049-057

Kumar, R. Goyal, K. G and Sanjeev M (2012). Antimicrobial activity of bark of Plumeria rubra. Journal of Pharmacy Research 5(8):4342-4343
Kumar S, Kumar V and Prakash O. (2011). Microscopic evaluation and physicochemical analysis of Dillenia indica leaf. Asian Pac. J Trop Biomed. 1: 337-340.

Kumar A, Chanda I, and Singh A (2009). Extraction and evaluation of pharmacological activity of saponins extract of Plumeria rubra leaves. Pharmacology online, 1: 969-974.

\section{Ilyas U, Katare D.P, Aeri V and Naseef P.P} (2016). A review on hepatoprotective and immunomodulatory herbal plants, Phcog Rev. 10 (19) : 66-70. https://doi. org/10.4103/0973- 7847.176544 PMid:27041876 PMCid:PMC4791991.

Odoemelam, S, Simeon-Ahaotu, V.C, Patricio De Los Ríos and Ahaotu, E.O (2020). Effects of Frangipanni (Plumeria Rubra) Leaf Meal as Feed Additive on the Performance and Egg Laying Index of HyLine Brown Birds. International Journal of Research in Agriculture and Forestry, 7 (2) : $1-6$.

Ogunwande I.A, Opoku A.R and Oladipupo A.L, (2015). Chemical composition of essential oils of Plumeria rubra L. grown in Nigeria. European J Med Plants. 6 (1):55- 61.

Oladipupo A, Lawal I and Opoku Y. (2015). Chemical Composition of Essential Oils of Plumeria rubra L Grown in Nigeria, European Journal of Medicinal Plants. 6:55-61. 
Radha, R, Kavimani, S and Ravichandran, V (2008). Antitumor activity of methanolic extract of Plumeria alba L. leaves against dalton lymphoma ascites in mice. International Journal of Health Research. 1(2):79-85.

Rasool SN, Jaheerunnisa S, Suresh Kumar and Jayaveera KN (2008). Antimicrobial activities of Plumeria acutifolia. Journal of Medicinal Plant Research. 2(4): 077-080.

Reddy YSR, Venkatesh S and Ravichandra T (1999). Pharmacognostical studies on Wrightia tinctoria bark, Pharmaceutical Biology, 37: 291-295.

Rupali . D and Alka .C. (2014). Phytochemical screening and antibacterial potential of natural dye: Plumeria rubra (L.). Sci. Res. Rept., 4(1):3134.

Santhi $\mathbf{R}$ (2010). Drug invention Today. 2(2): 112-144.

Singh B. A (2010). Antibacterial activity of Plumeria rubra Linn. Plant Extract., Journal of Chem. Pharm. Res., 2(6):435-440.

Sura J, Dwivedi, S and Dubey, R (2018). Pharmacological, phytochemical, and traditional uses of Plumeria alba LINN. an Indian medicinal plant. J Pharm Bio Sci 6(1):1-4.

Surendra K, Kumar N and Sharma, D (2012). Antimicrobial potential of Plumeria rubra syn Plumeria acutifolia bark, Der pharma chemical. 4:1591-1593.
Syakira MH and Brenda L (2010). Antibacterial Capacity of Plumeria alba Petals. World Academy of Science, Engineering Technology. 44:1473-1476.

Uduji, M.A, Uche, M.1, Simeon-Ahaotu, V.C, Patricio De Los Ríos and Ahaotu, E.O (2020). Effects of Frangipanni (Plumeria Rubra) Flower Meal as Feed Additive on the Performance and Egg Laying Index of Isa Brown Birds. International Journal of Research in Agriculture and Forestry. 7 (3) : $1-7$. 